Article

\title{
Consumer Acceptance and Value in Use-Oriented Product-Service Systems: Lessons from Swedish Consumer Goods Companies
}

\author{
Daniel Borg, Oksana Mont *(i) and Heather Schoonover \\ The International Institute for Industrial Environmental Economics (IIIEE), Lund University, Tegnérsplatsen 4, \\ 22100 Lund, Sweden; da3374bo-s@student.lu.se (D.B.); heather.schoonover@iiiee.lu.se (H.S.) \\ * Correspondence: oksana.mont@iiiee.lu.se; Tel.: +46-46-222-0250
}

Received: 2 September 2020; Accepted: 25 September 2020; Published: 30 September 2020

\begin{abstract}
In order to make our production and consumption systems more sustainable, there is a need to further explore and support novel business models with higher sustainability potential. Use-oriented product-service systems (u-PSS) are considered a promising alternative to traditional ownership-based business models, as they may result in lower environmental impacts. The presence of u-PSS in consumer goods markets, however, is still small. This is due in part to the nature of the products and lack of consumer acceptance of u-PSS. Lately, however, companies in Sweden have begun offering u-PSS for consumer goods, thereby challenging earlier findings. Understanding about how companies encourage consumers to select u-PSS over ownership-based options is still lacking. We investigate this question by conducting interviews with and analysing websites and publicly available company reports of seven Swedish companies from three consumer goods sectors: clothing, eyewear and furniture. We found that, while consumer barriers to u-PSS found in previous studies - uncertainty and trust, economics and costs and desire to own-persist, tailoring elements of u-PSS business models to different markets, sectors and consumer segments can help address these barriers and ensure u-PSS resonate with consumers. The study also applies the concept of consumer perceived value to show how emphasising different dimensions of value-financial, functional, emotional and social—provided by u-PSS may help increase their acceptance and adoption.
\end{abstract}

Keywords: consumer acceptance; consumer perceived value; use-oriented product-service systems; consumer goods; Sweden

\section{Introduction}

In 2015, all member states of the United Nations adopted the 2030 Agenda for Sustainable Development and the 17 Sustainable Development Goals (SDGs). Goal number 12 calls for urgent action to ensure sustainable consumption patterns and reduce the global material footprint [1]. Despite this, in 2019, Earth Overshoot Day came earlier than ever before, which meant that by 29 July, humanity had already used all the resources the planet could renew during the year [2]. The consumption patterns in many Western countries, such as Sweden, are unsustainable [3].

One explanation for unsustainable consumption is linear business models in which products are designed to last for a short period of time and are usually disposed of at the end of their first cycle of use. Business model innovation provides an opportunity to find more resource-efficient ways of creating and delivering value, and to drive consumer behaviour in a more sustainable direction [4]. Product-service systems (PSS) have emerged as one way to satisfy consumer needs in a less materially intensive way than traditional business models [5]. In use-oriented PSS (u-PSS), consumer needs are fulfilled through a combination of tangible products and intangible services, and consumers pay for 
access to product function instead of product ownership [6]. Such business models include renting, leasing and other types of access provision to consumers.

Companies are looking for alternative ways to create and deliver value to consumers in more sustainable ways, driven by institutional changes and increased demand [7]. Consumer awareness about the impacts of consumption is becoming more prominent [8], as is understanding of the sustainability potential of rental business models [9]. From a sustainability perspective, use-oriented product-service systems offer the possibility to decouple economic growth from the number of products sold [10], thereby reducing the pressure to produce new products from virgin raw materials [11]. By keeping ownership in the hands of companies, u-PSS can incentivise the production of more durable products [11] and the creation of systems for take-back and reuse [12]. In addition, useful product life can be extended through repair [13], upgrade [14] and refurbishing [15] as the products are seen as capital assets delivering product function. In addition, intensity of product use is often increased in u-PSS by serving multiple customers [11]. This keeps products out of the waste stream and potentially reduces the need for-and thus environmental impacts of-new production. From a company perspective, bundling products and services is an opportunity for companies to differentiate from traditional product offerings and improve their competitiveness through diversification of services rather than products [16]. Use-oriented product-service systems may also be a way to compete with the growing prevalence of e-commerce [17], and to lower barriers to purchase by offering a trial period [18].

So far, u-PSS have largely been adopted in business-to-business markets, such as for office equipment [19-21], where their acceptance level and feasibility are relatively high [11]. Their presence in consumer (B2C) markets, however, lags behind. The majority of B2C examples come from durable slow-moving products, such as cars, or from items that tend to be rented for a single use, such as formal attire or party supplies [22]. More basic consumer goods that are used on an ongoing basis, however, are often considered unsuitable for product-service systems, especially those that are inexpensive, used frequently, do not require maintenance, or are heavily influenced by fashion or branding [23]. At the same time, the highest environmental impacts of many of these products, including clothing and furniture, occur in the raw materials extraction and manufacturing phases [24,25], making them ripe for new business models that reduce the need for new production and use of virgin resources. It has been argued that it is difficult to develop u-PSS for these types of products, due to high barriers for developing financially feasible business models and low acceptance from consumers [22]. Despite this, several Swedish consumer goods companies have recently started exploring and offering u-PSS on the market, in sectors including clothing, home furnishings, and eyewear. The question then arises: How do companies encourage consumers to accept these use-oriented business models?

Studies of u-PSS have tended to focus on the preconditions for product-service systems rather than strategies of companies to involve consumers and ensure successful implementation on consumer markets [26]. Consumer attitudes towards u-PSS have been examined using surveys and interviews, where participants were presented with hypothetical scenarios of product-service systems [26,27]. However, the role of companies in influencing consumers to choose use-oriented options instead of ownership-based options is still an area where understanding is lacking [28]. Of particular interest is a question of how companies create sufficient value so that consumers deselect the so-far preferred option of product ownership [11,29]. Understanding how companies package and present their use-oriented offers to consumers, what consumer-related barriers they are experiencing, and what types of value they are promoting could help explain factors that shape consumer acceptance of u-PSS [30,31], and ultimately how PSSs diffuse onto the consumer market [29].

The aim of this study is to enhance understanding on how companies encourage adoption of u-PSS in everyday consumer goods sectors where ownership is the usual consumption mode. By comparing different perspectives on consumer acceptance and value in literature with the current practices of companies in Sweden, the research offers insights into how acceptance of u-PSS in unsuitable markets can be increased. The learnings from these existing business practices could be 
transferred to other consumer and geographical markets, and potentially drive change towards more sustainable consumption.

Following this aim, we ask the following questions:

1. What characterises u-PSS offerings in consumer goods sectors, including clothing, furniture and eyewear?

2. When introducing these u-PSS, what consumer-related barriers do B2C companies experience?

3. What types of consumer value may drive the adoption of these u-PSS, as perceived by B2C companies?

Our paper proceeds as follows: The next section reviews the literature to identify the current state of knowledge relevant to the three research questions and confirm knowledge gaps. An analytical framework based on this literature review is developed and presented at the end of the section. Section 3 describes the research methodology, including the process of conducting the literature review, the choice of case companies, and how data were collected and analysed. Section 4 presents the analysis of the empirical data compared to findings from the literature review. In Section 5, we discuss the main findings, draw conclusions, provide recommendations, and identify directions for future research.

\section{Literature Review}

\subsection{Characteristics of Use-Oriented Product-Service Systems}

The different types of PSS have different proportions of products and services included in the value delivered to the customer [6]. In product-oriented PSS, extra services are offered together with products that are sold to the consumer. In use-oriented PSS, the provider maintains ownership of the products, but provides the consumer access to products and services on temporary basis. Finally, result-oriented PSS are not based on offering a specific product but are rather based on the idea that the consumer is offered and pays for an end result. Use-oriented PSS differ from result-oriented PSS in that the extraction of value from a product is done by the user in use-oriented PSS, e.g., renting a lawn mower to mow grass, whereas in result-oriented PSS the product or equipment is operated by a service provider, e.g., the consumer pays a service company to mow the grass.

Use-oriented product-service systems can be defined as transactions between providers and consumers where temporary access to goods, instead of product ownership, is offered in return for a use-related fee [5]. Tukker [6] divides u-PSS into three types: leasing, renting or sharing and pooling. The different models share the idea of delivering access to a product function, rather than selling product ownership. One main difference is that in leasing, renting and sharing, products are used sequentially, while in pooling, products may be used simultaneously. The differences between the types are important when assessing environmental profiles of u-PSS, e.g., [32], as well as exploring their consumer acceptance [33]. In this study, we focus on leasing and renting and, because many companies use these terms interchangeably, we do as well. However, the specific rental or leasing business models companies employ differ, not only in terms of their product and service content [6], but also with respect to consumer-related elements including revenue models, delivery channels, target consumers and consumer relationships.

Examples of u-PSS in consumer goods markets are still somewhat limited, but include short- and long-term rentals of different types of products, e.g., [34], as well as membership-based models in 'libraries of things' [35]. For example, membership-based fashion libraries and rental of both adult and children's clothing are emerging in various countries [36-38]. Examples of furniture leasing for private individuals have also emerged in recent years [39], expanding beyond the business-to-business settings in which furniture leasing has traditionally taken place [19]. Pilot projects for renting baby products have also been conducted [40]. Still, Corvellec and Stål [41] suggest that u-PSS often operate at the margins of their industry and are still experimenting with different business models. A study of clothing libraries in Denmark, Sweden and Finland showed that $75 \%$ of them were run on a voluntary basis and were struggling to find a viable business model [37]. 
Even though u-PSS provide consumers with many benefits, such as flexibility and the opportunity to enjoy the latest products and styles without the burden and responsibilities of ownership [42], purchasing still seems to be the preferred alternative [43]. The barriers for successful implementation of a business model that allows for large-scale consumer adoption across industries have so far been difficult for companies to overcome [28].

\subsection{Barriers to Adoption of Use-Oriented PSS}

The review of existing literature identified a number of barriers to consumer acceptance of $\mathrm{u}$-PSS for consumer goods. The reviewed studies focused on consumer acceptance of u-PSS for consumer goods, both generally and for specific products, including clothing, home furnishings and baby products. The barriers can be classified into three categories based on common themes in literature [44,45]: (1) the novelty of the consumption mode and resulting issues with trust, (2) economic and cost-related barriers, and (3) barriers related to the desire to own.

Since u-PSS is a relatively new concept, many consumers experience a sense of uncertainty and lack of trust about the concept itself, the motives of the company behind the offering [26] or its workings on the market [27]. Lack of information about use practices [45], the terms and conditions [46,47] and the engagement expected from consumers once they have entered a leasing or rental contract $[36,48]$ are also found to be barriers. In addition, anxiety concerning who is responsible for the product if it breaks or is damaged can prevent consumer adoption [27,49]. Hygiene and cleanliness is also a concern among consumers, especially for such products as clothing [36,44,50] and home furnishings [27]. Uncertainty around the availability of products at the time when a consumer needs them can also be a challenge [36,51].

Consumers often seek options that provide them with good value for their money [44]. Paying for access instead of ownership could be financially beneficial if it means gaining access to goods that may otherwise not be affordable for the consumer [44]. such as renting clothes for special occasions. If, however, access is more expensive than buying, as can be the case with longer-term rental, this can constitute a barrier to consumer adoption of u-PSS [19,27]. In addition, when the costs of u-PSS are perceived to be greater than the benefits, consumers can be reluctant to choose this option [36,51], especially if there are additional fees for membership and other add-on services [36]. Use-oriented product-service systems also entail transaction costs, including search costs to establish the availability of the product, technical costs of retaining new knowledge about product rental and use, and sunk costs that cannot be recovered [51]. The ongoing nature of rental payments can also pose a financial risk for consumers [26,27].

The desire to own products has been shown to be a major barrier towards the adoption of u-PSS by consumers $[5,11,16,27]$. Since most people are used to purchasing and owning products, changing behaviour is associated with risk-taking. Consumers also perceive higher risks when purchasing services rather than products [52]. Owning products can give consumers a sense of control and freedom over their own decisions about product use and disposal, which is highly valued [11]. In addition, function without ownership is the premise for u-PSS, but products are not only consumed for their function [27,29,52]; they can also be consumed for emotional [53] and symbolic purposes [54]. In cases when owning products produces emotional attachment through feelings of self-identity and social belonging [29], as can be the case with clothing, or when products make us feel at home and give us a sense of security [55], as with furniture, it can be challenging for u-PSS to compete.

\subsection{Consumer Value as a Driver for Adoption of Use-Oriented PSS}

The idea of value creation for consumers is recurrent in literature on u-PSS. It is argued that if sufficient value is created, consumer behaviour could change [11,29]. The concept of consumer perceived value acknowledges that consumers derive different types of value from companies' offerings but it lacks a common definition. One perspective sees consumer perceived value as unidimensional, where value is based on the neoclassical idea of consumers as rational decision-makers who pursue maximised 
utility [56]. Consumer value therefore becomes a matter of trade-off between benefits and costs [56]. Other streams of research suggest that consumer value is complex and multidimensional $[56,57]$. The value trade-off includes not only economic parameters, but also time, convenience, quality and other benefits of using a product, and depends on when and in which context the weighing is being made [58].

A useful classification of consumer perceived value in retail purchase situations is offered by Sweeney and Soutar [59], who derive four dimensions of value based on their extensive perceived value (PERVAL) scale. These dimensions include price, emotional, quality and social value. Here we apply them in the context of u-PSS to understand the different types of value u-PSS can provide. Given that the PERVAL scale was developed in the context of consumer goods [59], we have changed these terms slightly to reflect the more complex nature and terminology of u-PSS. Namely, we use financial value in place of price value and functional value in place of quality value. By using all four value dimensions, the risk of overemphasis on functional value, as is typically promoted in PSS, can be reduced $[29,51]$.

Financial value refers to the value for money as compared to short- and long-term costs [59]. In the financial value dimension, a key driver for the adoption of u-PSS is the feeling of making a financially beneficial choice $[26,36,60]$. This could be the case when, for example, the cost of renting is lower than the cost of buying a product [27] or when u-PSS provide access to products of higher quality than the consumer otherwise could not afford [16]. Other financial drivers include the lack of initial investment needed in u-PSS [5] and avoidance of sudden costs due to repair and maintenance that can arise in the ownership model [26,49].

Functional value is the utility received based on the performance or quality of a product or service [59]. Functional value in the context of u-PSS can be derived from such factors as perceived flexibility $[27,61]$ and time savings [45]. Temporary access or access to products only when they are needed is also a driver for u-PSS, especially in temporary living situations or certain life stages such as having young children [29], or when there is only a periodic need for specific products, like garden tools [62]. Product customisation [16], such as better fitting clothes, is also seen as a source of functional value delivery through u-PSS. Ease of use has been mentioned as another important functional value in a recent study of online second-hand clothing rental platforms [63]. Emotional value relates to feelings and affective states generated by a product or service [59]. Emotional value in the context of u-PSS can include satisfying the need for novelty, reducing boredom, or giving the possibility to experiment with new brands or styles [36]. Relief from responsibilities of ownership [60], such as no longer needing to perform maintenance [10], can also contribute to emotional value. Feelings of doing good and potentially reducing consumption could drive acceptance of u-PSS among environmentally aware consumers [44].

Social value refers to value created in a social domain with regard to status or image associated with a product or service [59]. Drivers in the social value dimension in the context of $u$-PSS include feelings of belonging to a social group and enhanced social interaction when participating in u-PSS [36]. Social pressure has also shown to be a factor that drives consumers to use u-PSS [63]. Being socially responsible and caring for others by making environmental choices can also drive consumer acceptance of u-PSS [29]. Status consumption is also a strong motivator, so u-PSS that strengthen social status could have a greater chance of gaining consumer acceptance [42]. On the other hand, some studies report rather contradictory drivers for consumers to adopt u-PSS, e.g., environmental concerns and simultaneously a desire to own the latest model of a product [48].

\subsection{Analytical Framework}

The three building blocks of u-PSS characteristics, barriers and consumer value, as discussed in the above literature review, form the main elements of the analytical framework for this study (Figure 1). The development of an analytical framework is considered beneficial for guiding both data collection and analysis in case studies [64]. Each of these building blocks is further broken down into 
key features, to facilitate data collection and analysis in a systematic way. Characteristics comprise business model elements [65], as well as the product and service content [6]. Barriers are grouped into uncertainty and trust, economics and costs, and desire to own [44,45]. Consumer value is broken into financial, functional, emotional and social value that consumers derive from u-PSS [57]. Below, we apply this framework to our case companies to understand how the characteristics of u-PSS business offerings, the consumer barriers to u-PSS offers as perceived by companies and the types of value companies see as drivers for u-PSS, can contribute to acceptance and ultimately adoption of u-PSS in consumer goods markets. The framework guided the development of the interview questions used in semi-structured interviews with company experts, as well as the organisation of the results to facilitate their presentation, analysis, and discussion.

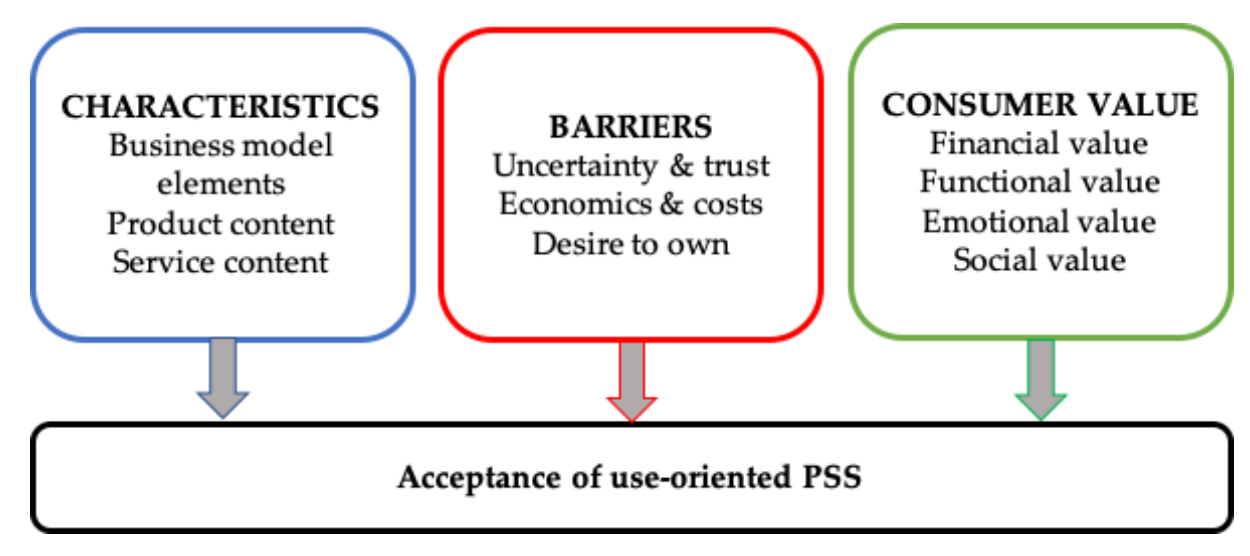

Figure 1. Analytical framework.

\section{Methods}

Although knowledge exists on what influences consumer acceptance of products, much less is known about consumer acceptance of PSS and especially u-PSS in consumer goods markets. Therefore, we deemed a case study methodology suitable for generating necessary knowledge on a contemporary phenomenon [64]. We chose a multiple-case approach to collect information across sectors, making it more possible to generalise across markets $[66,67]$. Each case is built on both secondary and empirical data, the latter collected through semi-structured interviews.

\subsection{Literature Review}

"A literature review is a systematic, explicit, and reproducible design for identifying, evaluating, and interpreting the existing body of recorded documents" [68]. The above literature review was guided by the research questions [69] and was conducted to understand the current state of knowledge [70] regarding consumer acceptance of product-service systems and use-oriented PSS, barriers to consumer acceptance of PSS and value for consumers generated from u-PSS for consumer goods. The literature review was conducted between March and September 2020. We examined academic publications in Scopus, the largest multi-disciplinary database of peer-reviewed literature. The literature review was conducted in three steps, inspired by guides for conducting more systematic types of literature reviews [71].

Step 1: Identifying publications and applying practical screening. We started by developing screening criteria to ensure that quality publications were included in the review. The first criteria included 'peer-reviewed journal articles and peer-reviewed conference papers' and excluded commentaries, working papers and book reviews. Only publications in English were included. The main search terms used included 'product service systems', 'consumer acceptance', 'use-oriented PSS', 'access-based consumption', 'barriers', 'rental fashion', 'renting clothes', 'consumer perceived value', and 'consumer value', 'furniture', 'eyewear', 'clothes', 'fashion' and 'textiles'. We ran 17 search strings combining these different keywords, e.g., [ALL ('use-oriented PSS' OR 'use-oriented product service 
systems') AND ALL ('consumer acceptance')]. This resulted in 486 articles that addressed consumer acceptance, barriers to and value for consumers from PSS in general and from use-oriented PSS in the consumer goods sector.

Step 2: Applying theoretical screening criteria. Guided by the purpose of the study we then read the titles, abstracts and keywords of these conceptual and empirical articles and conference papers. Additional criterial included an explicit focus on business-to-consumer markets, i.e., consumer goods. However, papers that studied end-user acceptance and perceived value of use-oriented PSS in business-to-business markets from the target sectors, namely furniture, were also included due to the lack of studies about the B2C market. Papers that included u-PSS in addition to other forms of consumption, including sharing economy, collaborative consumption, peer-to-peer exchanges and purchasing products second hand were included, although analysis was limited to the aspects relevant to u-PSS. Articles that focused on aspects of u-PSS including product design and implementation without considering consumer acceptance or consumer perceived value, as well as articles that focused on product-oriented PSS or result-oriented PSS, were excluded. As a result of this screening, 364 articles were excluded, leaving 122 articles in the list.

Step 3: Final filtering and analysis. The next step was to exclude articles that appeared several times in the results of different search strings. There were 47 such articles, resulting in the final list of 75 unique articles. These articles were then read and qualitatively analysed. For that a categorization matrix was developed guided by prior knowledge about characteristics of PSS, e.g., [10], barriers to PSS [72] and consumer acceptance of PSS [52], as well as the streamlined model for consumer perceived value that is used in retail research [57].

\subsection{Case Studies}

The empirical study followed a three-step procedure: identification of possible cases, selection and analysis of relevant cases and practitioner interviews. We chose to focus on Sweden because it has recently seen the introduction of u-PSS for consumer goods across multiple sectors, including eyewear, the latter of which has not yet been explored in literature. In addition, the number of companies engaged in u-PSS suggested we would be able to find multiple examples within each sector. For selection criteria, we specified that the company should be, or should have been, active in the consumer goods market in Sweden, and that u-PSS in the form of leasing or rental should have been, or is planned to be, introduced to individual consumers as an alternative to purchasing products. Since we were interested in products previously deemed unsuitable for u-PSS, we also specified that the companies' products should be relatively inexpensive, used frequently or on an ongoing basis, influenced by fashion or branding, and not require much maintenance. Companies offering products that are usually rented for a specific occasion, such as sports equipment, were thus not included.

Official open-access business documents (e.g., company reports), grey and business literature from sectors and companies, and online sources, including company websites were sources of information for the selection of cases, and also later contributed information about business model characteristics and consumer value for data analysis. Fieldwork was also carried out through observations in stores and by talking to employees at potential case companies. This was a complementary approach to qualify or eliminate potential cases depending on the fulfilment of the selection criteria Our initial search resulted in 18 potential companies, of which 7 agreed to participate in the study. The final selection comprised seven companies from three consumer goods sectors: clothing, eyewear and furniture. The selected case companies are described in Table 1. 
Table 1. Case companies.

\begin{tabular}{|c|c|c|}
\hline Sector & Company & Description \\
\hline \multirow{3}{*}{ Clothing } & Hyber & $\begin{array}{l}\text { Founded in } 2015 \text { with the ambition to introduce a circular business } \\
\text { model for families with children. Offers rental of quality children's } \\
\text { clothes in Sweden through a membership-based subscription. }\end{array}$ \\
\hline & Sabina \& Friends & $\begin{array}{l}\text { Founded in } 2010 \text { with the ambition to change the fashion industry } \\
\text { through a new way of consuming clothes. Offers rental of } \\
\text { higher-end fashion through a membership-based subscription or } \\
\text { one-off rental. }\end{array}$ \\
\hline & MQ (MarQet) & $\begin{array}{l}\text { Founded in } 1957 \text { focusing on men's and women's clothing. } \\
\text { Operates the largest chain of fashion concept-stores in Sweden. } \\
\text { Launched rental of women's clothes as a circular business model } \\
\text { trial together with Something Borrowed in } 2019 \text {. }\end{array}$ \\
\hline \multirow{2}{*}{ Eyewear } & Synoptik & $\begin{array}{l}\text { Founded in Denmark and established in Sweden in 1991. Operates } \\
\text { over } 140 \text { stores and is a leading actor in the eyewear industry. } \\
\text { Introduced subscription-based rental of glasses in May } 2019 .\end{array}$ \\
\hline & Synsam & $\begin{array}{l}\text { Synsam Group is a leading actor within the eyewear industry with } \\
\text { over } 450 \text { stores in the Nordic countries. Introduced } \\
\text { subscription-based rental of glasses in } 2016 .\end{array}$ \\
\hline \multirow[b]{2}{*}{ Furniture } & Hemmlis & $\begin{array}{l}\text { Launched as a pilot in } 2017 \text { and continued as a Vinnova-funded } \\
\text { project during } 2018 \text { in Lund, Sweden. Offered subscription-based } \\
\text { rental of furniture to students in Lund. Operation was put on hold } \\
\text { as of the end of } 2018 \text {. }\end{array}$ \\
\hline & IKEA & $\begin{array}{l}\text { Founded } 1943 \text { in Älmhult, Sweden. A global actor in the home } \\
\text { furnishing industry with } 422 \text { stores in } 50 \text { markets. Announced the } \\
\text { testing of furniture leasing models intending to develop } \\
\text { subscription-based leasing offers or "furniture as a service" in } \\
\text { spring } 2019 .\end{array}$ \\
\hline
\end{tabular}

Source: Practitioner interviews and company webpages (www.hyber.com, www.sabinaandfriends.se, www. marqetstores.se, www.synoptik.se, www.synsam.se, www.hemmlis.se, www.ikea.se, www.ingka.com).

Once the relevant companies were selected, a key informant was identified within each company. Since the key informant needed to have experience with consumers considering rental, this was usually a person working with or in close relation to the marketing, business development or sales functions of the company. Interview questions focused on the companies' business model characteristics, consumer-related barriers they have experienced, and the different dimensions of value they see as important and/or communicate to consumers (the interview guide is available upon request). The interviews were either recorded and transcribed, or extensive notes were taken when consent for recording had not been granted. Data analysis was both deductive and inductive, with data coded according to the categories from the analytical framework, but also open to new factors, strategies and answers to the research questions.

\section{Analysis}

\subsection{Characteristics of u-PSS in B2C Markets in Sweden}

All the case companies share similar u-PSS characteristics. They all provide bundles of products and services to final consumers, who pay a fee for access to products owned by the providers. However, the companies have diverse business model designs, with differences in consumer-related elements including revenue models, delivery channels, target consumers and consumer relationships. These characteristics are presented in Table 2 below and explained further in text. 
Table 2. Summary of use-oriented product-service systems characteristics of the case companies.

\begin{tabular}{|c|c|c|c|}
\hline Company & Business Model Elements & Product Content & Service Content \\
\hline Hyber & $\begin{array}{l}\text { Type-rental membership-based } \\
\text { Duration-3-12 months. } \\
\text { Ongoing with one-month termination } \\
\text { notice before next period starts. } \\
\text { Channels—online. } \\
\text { Customer segment-families with } \\
\text { small kids. } \\
\text { Customer relationship—Online self-service. }\end{array}$ & $\begin{array}{l}\text { Children's clothes } \\
\text { Focus on quality, function } \\
\text { and outdoor. } \\
\text { Different sets of clothes } \\
\text { depending on season and } \\
\text { functionality. } \\
\text { No own brands-working } \\
\text { with partners "premium } \\
\text { brands". }\end{array}$ & $\begin{array}{l}\text { Repair, laundry, } \\
\text { reconditioning. } \\
\text { Change size free of } \\
\text { charge-"no more clothes to } \\
\text { grow into". } \\
\text { Home delivery. } \\
\text { Clothes new or as good as new. } \\
\text { Quality guaranteed. } \\
\text { End of use handling. }\end{array}$ \\
\hline $\begin{array}{c}\text { Sabina \& } \\
\text { Friends }\end{array}$ & $\begin{array}{l}\text { Type-rental membership-based and } \\
\text { one-off rental. } \\
\text { Duration-monthly or one-off } \\
\text { Ongoing with one-month } \\
\text { termination notice. } \\
\text { Channels-one physical shop and online. } \\
\text { Customer segment-Women } 30-50 \text {, higher } \\
\text { income level, environmentally conscious. } \\
\text { Customer relationship-in store personal } \\
\text { assistance and online self-service. }\end{array}$ & $\begin{array}{l}\text { "Higher level" fashion-a } \\
\text { bit more exclusive. } \\
\text { Designer clothes—no own } \\
\text { brands. } \\
\text { Focus-quality, } \\
\text { sustainability, European } \\
\text { brands (Made in Europe). } \\
4 \text { different memberships } \\
\text { depending on number of } \\
\text { clothing items and service } \\
\text { level. }\end{array}$ & $\begin{array}{l}\text { Repair, laundry, } \\
\text { reconditioning. } \\
\text { Showroom with personal } \\
\text { styling and fashion advice. } \\
\text { Home delivery or in store } \\
\text { pick-up. } \\
\text { Handpicked clothes from } \\
\text { latest collection-unique mix } \\
\text { of brands and fashion items. } \\
\text { Clothes new or as good as new. } \\
\text { End of use handling. }\end{array}$ \\
\hline $\begin{array}{c}\text { MQ } \\
\text { (MarQet) }\end{array}$ & $\begin{array}{l}\text { Type-rental subscription-based through } \\
\text { third party partner, (Something } \\
\text { Borrowed, SB). } \\
\text { Duration-monthly. } \\
\text { Channels-Online. } \\
\text { Customer segment-Women. } \\
\text { Customer relationship-Online self -service } \\
\text { or online personal service. }\end{array}$ & $\begin{array}{l}\text { Clothes for women-fast } \\
\text { fashion and street fashion } \\
\text { brands. (SB) } \\
\text { Different subscriptions } \\
\text { depending on service level } \\
\text { and number of items per } \\
\text { month. (SB) } \\
\text { In-house brands by MQ. } \\
\text { (MarQet) }\end{array}$ & $\begin{array}{l}\text { Repair, laundry, } \\
\text { reconditioning. (SB) } \\
\text { Personal styling as a possible } \\
\text { option. (SB) } \\
\text { End of use handling. }\end{array}$ \\
\hline Synoptik & $\begin{array}{l}\text { Type-rental subscription-based } \\
\text { Duration-24 months. } \\
\text { Channels-through Synoptik stores. } \\
\text { Customer segment-all customers. } \\
\text { Customer relationship-personal assistance } \\
\text { in store. }\end{array}$ & $\begin{array}{l}\text { Eyewear-all types of } \\
\text { glasses (everyday glasses, } \\
\text { sunglasses, reading glasses, } \\
\text { computer glasses etc.). } \\
\text { Minimum } 3 \text { pairs of glasses. }\end{array}$ & $\begin{array}{l}\text { Regular eye exams once a year. } \\
\text { Insurance-accidents. } \\
\text { Repair (normal, minor). } \\
\text { Option to change one pair } \\
\text { every year. } \\
\text { New lenses in case of changes } \\
\text { in eyesight. } \\
\text { End of use handling. }\end{array}$ \\
\hline Synsam & $\begin{array}{l}\text { Type-rental subscription-based. } \\
\text { Duration-24 months. } \\
\text { Channels-through Synsam stores. } \\
\text { Customer segment-all customers. } \\
\text { Customer relationship-personal assistance } \\
\text { in store. }\end{array}$ & $\begin{array}{l}\text { Eyewear-all types of } \\
\text { glasses in categories (normal, } \\
\text { reading, sun, sports etc.) } \\
3-10 \text { pairs of glasses. } \\
\text { All types of lenses. }\end{array}$ & $\begin{array}{l}\text { Regular eye exams once a year. } \\
\text { Insurance covering theft, } \\
\text { damage, loss. } \\
\text { Option to change one pair } \\
\text { every year. } \\
\text { New lenses in case of changes } \\
\text { in eyesight. } \\
\text { Cleaning products included. } \\
\text { End of use handling. }\end{array}$ \\
\hline IKEA & $\begin{array}{l}\text { Type-trials of subscription-based leasing } \\
\text { offers, furniture as a service subscription. } \\
\text { Duration-to be defined (TBD) } \\
\text { Channels-TBD. } \\
\text { Customer Segments-B2C, B2B Public } \\
\text { procurement } \\
\text { Customer relationship_-TBD }\end{array}$ & $\begin{array}{l}\text { Testing different ranges of } \\
\text { IKEA products on selected } \\
\text { markets. Home furnishing } \\
\text { and office furniture. }\end{array}$ & $\begin{array}{l}\text { Testing of different types of } \\
\text { services on different markets, } \\
\text { e.g., leasing of furnishing } \\
\text { packages to students. } \\
\text { Focus on: Affordable, } \\
\text { Accessible, Sustainable. }\end{array}$ \\
\hline Hemmlis & $\begin{array}{l}\text { Type-Rental. } \\
\text { Duration-Minimum one semester ( } 5 \\
\text { months). } \\
\text { Channels-Online. } \\
\text { Customer segment-Students. } \\
\text { Customer relationship—On site delivery, } \\
\text { personal delivery. }\end{array}$ & $\begin{array}{l}\text { Second-hand furniture. } \\
\text { Fixed combos ( } 6 \text { pieces) } \\
\text { Bed, desk, table, chair, shelf } \\
\text { \& stand. }\end{array}$ & $\begin{array}{l}\text { Delivery. } \\
\text { Cleaning. } \\
\text { Upcycling. } \\
\text { End of use handling, no } \\
\text { disposal or sales needed. }\end{array}$ \\
\hline
\end{tabular}




\subsubsection{Business Model Elements}

In terms of revenue models, the three clothing companies all have a membership-based model, while the two eyewear companies and the Hemmlis furniture company employ a subscription-based model in which the user has individual and unlimited access to the products for a longer time period. Both the membership and subscription revenue models use a monthly fee during the contract period, but differ in terms of contract length and flexibility of cancellation. MQ (MarQet) and Sabina \& Friends have ongoing contracts but are also the most flexible, requiring just one-month notice prior to cancellation. Sabina \& Friends has also introduced one-off rental to increase flexibility and attract consumers not willing or hesitant to become long-term members. The standard contract of the children's clothing company, Hyber, is 12 months, with some exceptions for particular items. The eyewear companies have the longest contract period, 24 months. Hemmlis offers furniture rentals with the shortest contract period of 5 months, corresponding to one university term.

The companies also present a range of delivery channels, target consumers and consumer relationships. MQ offers its own in-house brands online through a partner (Something Borrowed) that handles all the activities related to the u-PSS offer. Sabina \& Friends works with external brands through their own online channel, as well as a physical store and showroom. Hyber is a market mediator working with external brands and partnering companies to manage a use-oriented platform and promote other companies' products online. Women are the main target group for the first two companies, while Hyber focuses on parents with small children.

The diversity of models across the clothing companies could reflect the findings from literature, that u-PSS in consumer markets are still at the experimental stage of business model development and operate on the margins of their industries [41]. In contrast, in the eyewear market, the characteristics of u-PSS are more homogeneous, and both case companies are larger established actors. Their subscription models are run through their traditional channels, with the physical store being the main channel and the eye examination being the starting point of the relationship with consumers. Potential customers are found among the existing customer segments, and the product range covered by the u-PSS is the existing range already available for purchase.

\subsubsection{Product Content}

All the products in our cases are products that previous research deemed unsuitable for u-PSS, i.e., products for everyday use that are not technically advanced, do not require regular maintenance, and are influenced by fashion and branding. Nevertheless, there are significant differences between them, including use cycles and the newness of the products. For example, Hyber's children's clothes naturally have a use span based on when children outgrow the garments, while the use span of Hemmlis' student furniture is based on the length of an academic term. The use span for clothing offered by Sabina \& Friends and MQ is set by the companies themselves, at one month. The clothing companies offer a mix of new and used clothes but communicate to their customers that the look and feel of the clothes is always as good as new. Hemmlis offers second-hand products and, in contrast to the clothing companies, is the only company in the study that explicitly communicates that the products are second-hand. The eyewear companies offer only new products, which are either donated or recycled after the first customer.

\subsubsection{Service Content}

All the companies provide repair and maintenance services. The clothing companies also offer laundry and reconditioning services to ensure the clothes are in desirable condition for the next user. The importance of hygiene in u-PSS identified in literature $[27,44]$ was confirmed in our interviews, which showed that these services help build trust and consumer loyalty. The eyewear companies offer an all-inclusive package that includes an eye examination, multiple pairs of glasses and repair services. Since consumers already come to the stores for the eye examination, delivery of eyewear products 
takes place in-store, whereas the clothing companies and Hemmlis offer home delivery. Flexible and customised offers, such as the ability to change products during the contract period, are found across product categories. The seemingly least flexible offer is the furniture rental, which includes the bulkiest products that are most difficult to handle. Personal styling and advice are promoted in both the clothing and eyewear sectors.

Reflecting on the u-PSS characteristics described above-business model elements, and product and service content - it is evident that the companies have shaped their offers to the needs of different consumer segments and the sectors in which they operate. This, in turn, can help to increase consumer adoption and avoid some of the barriers discussed in the next section.

\subsection{Barriers to Adoption of $u$-PSS, as Perceived by Companies}

\subsubsection{Uncertainty and Lack of Trust}

Confirming the findings in earlier research $[4,45]$, the majority of the interviewees identified novelty and the lack of knowledge and experience of u-PSS as a critical barrier for their consumers. Another barrier found in literature [27] and confirmed by interviewees was consumer uncertainty regarding rules and responsibility in case a product is damaged, broken or lost. This concern was especially prominent when leasing children's clothing, which is naturally subject to extensive wear and tear.

Hygiene has been found to be a critical factor for acceptance of u-PSS, especially relevant in the clothing sector and particularly for garments worn closer to the skin [44]. In our cases, hygiene and proper sanitisation of clothes was also important for renting children's outdoor clothing. Hygiene was not mentioned as a barrier by interviewees from the eyewear sector, probably because both eyewear companies lease new products. Offering second-hand clothes and furniture faces another barrier-lost history of product use-when consumers do not know who used the product before them. Another barrier that is not often discussed in literature is the increasing speed of fashion cycles, which can make clothing outdated even on the second-hand and u-PSS markets. To avoid this barrier, all three clothing companies rent garments that are frequently updated and picked from the latest collections. As expressed by one interviewee: "Yes, the clothes may have been used by others, but they are not old".

\subsubsection{Economic Obstacles and Other Costs}

Previous studies have shown that consumers are reluctant to choose u-PSS if the price is higher or even the same as in ownership-based models [27,44,51]. Our interviews confirm this, especially in low-price categories, where a relatively high rental price discourages consumers from trying u-PSS. As one of the interviewees stated, "It is just too easy to buy them". Extra effort of renting products and additional transaction costs associated with, e.g., search costs [51] were discussed by three of the interviewees. Use-oriented product-service systems are also sometimes seen by consumers as a less flexible option that needs more research and planning. The inability to be spontaneous when making choices could be a potential barrier.

All the interviewees mentioned that the recurrent payments during the contract period were seen as problematic for some consumers, who sometimes prefer to pay the entire rental fee at once. Especially for longer-term contracts, consumers perceive paying over a longer period to be financially risky and potentially more expensive, which is also confirmed by earlier studies [27]. In addition, one of the interviewees mentioned the difficulty of comparing the price of an ownership model with $\mathrm{u}$-PSS, as in the latter a diverse range of services is added, and prices may fluctuate. If the full value of u-PSS is not clearly explained in a way to make comparison possible, it could constitute a barrier for consumers. On the other hand, interviewees did not regard the stock out risk [44] as a barrier. 


\subsubsection{Desire to Own}

All the interviewees mentioned the difficulty of influencing consumer behaviour due to consumers' desire to own. Desire to own is associated with a perception of flexibility, freedom and control [11,60], fear of losing which was sometimes mentioned by consumers to the companies. The lack of freedom and control was exemplified by one interviewee, who described how consumers were unwilling to return garments after the contract period and wanted to keep them instead. Creating feelings for and strong bonds with products has been shown to be a strong barrier to adoption of u-PSS [53,55]. One reason found in literature as to why consumers would be interested in relinquishing ownership was if product ownership was perceived as high-risk [38]. However, none of the consumer goods in this study were high-risk.

In addition to addressing consumer barriers directly, to drive behavioural change towards u-PSS companies also need to demonstrate consumer value [31], which is discussed in the next section.

\subsection{Consumer Value Perceived by Companies as Influential for the Adoption of $u$-PSS}

The interviewed company representatives identified various types of value that could help shift consumer choice towards u-PSS. These values were perceived to be important for consumer adoption, based on feedback from their consumers, and/or were communicated to consumers by the companies.

\subsubsection{Financial Value as a Driver}

Previous studies have highlighted the importance for consumers to feel that they have gotten a good value for their money $[26,36,60]$. The importance of price and value for money is reinforced by our interviews. Five of the interviewees stressed that u-PSS can be cheaper than owning, particularly for temporary or short-term use. They are also a way to spread costs over time, which may lead to other benefits, such as freeing up resources to access other high-quality products $[16,27]$. For some consumers, the ongoing payments involved in u-PSS were associated with financial risks while, for others, u-PSS were considered a financially more secure option that allowed them to keep control over costs and plan expenses. They were also seen as a way to avoid sudden surprises if there was a need to change a product. The need not to spend money if a product breaks or is damaged was also considered to be a driver, especially for u-PSS that include upgrading, maintenance, repair and/or insurance [38,62]. For consumers who may be hesitant to commit to long rental periods [73], two companies introduced shorter contract periods to convince first-time users to try u-PSS. Using a short-term contract as a steppingstone to a longer-term commitment was not discussed in the reviewed literature.

\subsubsection{Functional Value as a Driver}

One of the advantages of u-PSS for consumers is the opportunity to change products [27,45]. All the interviewees mentioned flexibility as an important value for consumers, although they defined it differently. For some, it referred to the length of u-PSS contracts. For others it meant having a choice between different options or being able to change products and styles more frequently than if they owned the products. Subscribing to offers customised to a life situation, style and preferences was also identified as benefits of u-PSS, as was also reported in the literature [16,36]. Saving time and making life easier, such as by letting someone else ensure consumers' needs are met and handling products at the end of their use, were mentioned by three interviewees, confirming findings in the literature $[10,27,29]$.

\subsubsection{Emotional Value as a Driver}

In earlier research, freedom from responsibilities associated with product ownership was reported as an important driver for consumers to try u-PSS [10,60]. This was confirmed by four interviewees. In contrast, the reduced risk of buying the wrong product [42] was not mentioned in our interviews. Other emotional values discussed during the interviews were a feeling of 'fun' when trying a new 
concept and the "luxury" associated with the possibility to change products and extend services in u-PSS. Experimenting with new styles also fulfilled a consumer need for novelty [36]. Companies also reported that some consumers saw their engagement in u-PSS as a more sustainable form of consumption. These sustainability aspects can be viewed from the individual perspective, but they can also be seen as part of a social driver.

\subsubsection{Social Value as a Driver}

The pressure on consumers to make environmentally sound choices in their daily lives is something that receives attention in the media, and could be passed on to individuals through their peers or community [63]. Earlier research found that feelings of doing good and avoiding unsustainable consumption are values that increase the likelihood of u-PSS becoming successful on the market $[29,36]$. Sustainability as a driver was reported by all interviewees. For example, their consumers expressed joining u-PSS as "taking responsibility and giving products a second life" and as "consuming without feeling guilty". The latter statement confirms findings from recent studies where seemingly contradictory drivers, e.g., shaping social status through luxury apparel rental and sustainability aspirations, have been reported to influence consumer acceptance of u-PSS [48,74]. However, sustainability was often not the most prominent consumer value, nor is it a primary value communicated by the case companies. In addition, while consuming without feelings of guilt was mentioned by several interviewees, opinions diverged as to how important it really was compared to other factors. One interviewee saw sustainability not as an added value for consumers, but rather as a must-have for companies. Nowadays, a company would not be considered a serious provider if it did not work with sustainability.

\section{Discussion and Conclusions}

Use-oriented product-service systems are considered a promising alternative to traditional business models based on ownership, and have the potential to reduce the environmental impacts of consumption. However, their diffusion in consumer markets has been slow. This is partially explained by the nature of products in consumer markets [75] and associated difficulties for consumers to accept u-PSS [52]. Lately, however, some large and small actors in Sweden have started offering or piloting u-PSS, thereby challenging the earlier truths. Understanding about how companies encourage consumers to choose u-PSS and deselect ownership-based models is still lacking. Such knowledge is necessary in order to increase the adoption, and hence realise the sustainability benefits, of u-PSS.

This study gathered information about a dynamic transformation of business and consumption practices, through company materials and interviews with practitioners currently working with the development of u-PSS. Three areas that guided the study were explored: (1) business model characteristics, (2) consumer-related barriers and (3) consumer perceived value. Specifically, the study included findings about how the companies from three sectors-clothing, eyewear and furniture-perceive the barriers and value dimensions that influence the decisions of their customers with regard to u-PSS acceptance, and how they structure their u-PSS business models.

The results show that $\mathrm{u}$-PSS offerings in the Swedish markets are characterised by a mix of products and services tailored to their specific sector and customer groups. Different consumers have different needs and perceive different barriers, and this is reflected in the business model elements chosen by the case companies in this study. For example, the use of memberships in the clothing industry could reflect the need to address barriers relating to trust and hygiene. Certain aspects could be communicated that would signal common values among members, which in turn could build trust and facilitate consumer adoption. Concerns around hygiene can also be reduced if a person belongs to the same group as others with whom they are sharing products [36]. Offering services such as laundry and reconditioning, and communicating that their products are as good as new, are other ways companies address hygiene concerns associated with clothing. On the other hand, some business 
model elements are common across sectors. The ability to change products during the contract period and the inclusion of repair services probably address consumer uncertainty about u-PSS generally.

The introduction of use-oriented models also seems to follow patterns that are already familiar to customers in the relevant industry, and therefore could facilitate customer adoption. For example, the fact that eyewear rental comprises familiar factors, such as an eye examination, in-person interactions in stores and existing product ranges, means that in some respects it is not that different from the traditional sales model. In addition, subscriptions for contact lenses have been used for a number of years. For customers used to this leasing model, the idea of a subscription for glasses might be easier to adopt than a new concept such as membership. Similarly, when it comes to furniture, renting tables, chairs and other furniture for a birthday party or student graduation party already exists on the Swedish market. Transferring the concept of renting furniture for longer periods in everyday life is probably not such an abstract concept. Reducing the uncertainty with the concept of product-service systems has been found to be key in their success [26].

While companies demonstrated different degrees of innovation when designing u-PSS, their offers generally comprised products and services already available on the market. For products, this may be because the majority of the companies do not produce their own goods, and instead use private labels or external brands either produced, bought or offered through partnerships with brand owners. Only one of the interviewed retailers has a goal of changing their product lines to suit the circular nature of upcoming new business models. Many of the services in the u-PSS, such as cleaning, repair, delivery and end-of-use handling, are also already available for owned products, although not usually as a package deal from the seller of the products. The novelty of u-PSS for the consumer is in part the convenience of only having to deal with one actor to achieve the same range of services otherwise delivered by several actors.

The fact that u-PSS can be seen as more convenient than owning highlights the point that, while some consumer barriers can be reduced or eliminated, an additional strategy is to create sufficient consumer perceived value that outweighs the barriers. In this way, consumers may perceive the new alternative as superior. For example, sources of financial value reported by the companies, such as having more resources to access other products and avoiding surprise costs for repair, could offset consumers' concerns about costs and financial risks associated with u-PSS. Similarly, the option to change products more frequently than when owning (functional value), and feeling free from the responsibilities of ownership (emotional value), could counteract perceptions that moving away from ownership means giving up freedom and control. All these factors could also increase perceptions of value for money.

The fact that financial, functional, and emotional value were found to be more prominent than social value among the companies we interviewed also has implications for what value to communicate to consumers. This suggests that the strategy for promoting use-oriented PSS should not be based on social or environmental value but should instead focus on value for the individual consumer.

Based on the knowledge gathered in this study, three recommendations are offered to practitioners that could help increase consumer acceptance and ultimately diffusion of u-PSS in consumer markets:

- Minimise the need for consumers to change their behaviour. Designing u-PSS to resemble the traditional ownership-based offer in at least some aspects could help reduce feelings of unfamiliarity and uncertainty about u-PSS and burdens associated with access [76]. This could be done by using familiar channels or including services already associated with ownership of the product, for example.

- Lower barriers to trial for u-PSS. Making it easier for consumers to test but not immediately commit to u-PSS offers could reduce the perception of risk and provide consumers with the information, experience, and confidence to overcome uncertainties and convince them to pursue $\mathrm{u}$-PSS in the longer term. 
- Focus on communicating individual value creation for the consumer, understanding the diversity of value dimensions and their importance to different consumers. While social value may indeed be provided by u-PSS, the companies in our study did not find it to be a primary value for their consumers.

This study contributes to the growing body of research on use-oriented product-services systems, with valuable empirical knowledge about consumer acceptance as perceived by companies offering $\mathrm{u}$-PSS. We found that, while barriers to u-PSS previously addressed in literature may not have changed during the recent decades of research, there are specific factors that need to be considered when developing u-PSS business models for different markets, sectors and consumer segments in order for them to resonate with consumers. The study also empirically explored barriers and business models in the setting of consumer goods and business-to-consumer markets that were previously identified as unsuitable for u-PSS [75]. Finally, the study applied the concept of consumer perceived value to u-PSS in consumer goods markets, and showed how emphasising different dimensions of value may help increase consumer acceptance and ultimately adoption of u-PSS. This, in turn, can help realise the sustainability potential of $\mathrm{u}$-PSS.

At the same time, the study has certain limitations that should be considered when evaluating the results. First, the study has Sweden as the geographical scope. This is because there has recently been a development in the Swedish consumer market with companies introducing use-oriented models as an alternative to ownership models. Second, the study explored use-oriented PSS in three sectors. The reason for not focusing the research on only one sector is the still rather limited population of B2C companies working with use-oriented models today. In addition, the cross-sectoral study facilitates the transfer of knowledge between the sectors and business models. Third, since consumer acceptance was identified as one of the critical factors hampering the implementation and scaling up of u-PSS in different sectors, the purpose of this study was not to assess environmental sustainability of u-PSS as such, but rather to understand factors that can enable u-PSS penetration in different markets, thereby potentially reducing environmental impacts of production-consumption systems. That said, we acknowledge the importance of assessing the environmental sustainability of u-PSS in different sectors, through developing various use-oriented scenarios, as we have previously done in other studies $[32,62,77,78]$. Finally, understanding consumer acceptance and perceived value by focusing on companies' strategies to engage consumers may also be considered a limitation.

Considering the aforementioned limitations, future research could explore how to overcome consumer hesitation to engage with u-PSS by focusing not on only companies, but also on consumers through surveys or experiments. An important follow-up study could be to compare the companies' strategies for overcoming lack of consumer acceptance with consumers' ideas for how the penetration of u-PSS in different sectors can be improved by reducing consumer related barriers. Conducting a study similar to the one presented here but in other geographical areas could expand the number of companies per sector and could help unveil potential cross-cultural differences in consumer related barriers to accept u-PSS, as well as strategies companies employ to overcome or reduce them. Another area for future research could be to employ the full PERVAL scale to explore the sources of value that affect consumer decision-making in use-oriented product service systems.

Author Contributions: Conceptualization, D.B., O.M. and H.S.; methodology, D.B. and O.M.; formal analysis, D.B.; investigation, D.B.; resources, D.B. and O.M.; data curation, D.B., and O.M.; writing - original draft preparation, D.B., O.M. and H.S.; writing-review and editing, O.M. and H.S.; visualization, D.B. and O.M.; supervision, O.M.; project administration, O.M.; funding acquisition, O.M. All authors have read and agreed to the published version of the manuscript.

Funding: This research was funded by Mistra-the Swedish foundation for strategic environmental research, through the research programme Mistra Sustainable Consumption (programme period 2017-2021). Data were collected as part of a master's thesis and not funded by the programme.

Acknowledgments: The authors would like to thank the case companies for their invaluable time and support for this study. We would also like to thank MISTRA Sustainable Consumption-from Niche to Mainstream for financial support in conducting the research and the open access fees. 
Conflicts of Interest: Authors declare no conflicts of interest. The funders had no role in the design of the study; in the collection, analyses, or interpretation of data; in the writing of the manuscript; or in the decision to publish the results.

\section{References}

1. Sustainable Development Knowledge Platform. Available online: https://sustainabledevelopment.un.org/ sdgs (accessed on 5 December 2019).

2. Earth Overshoot Day 2019. Available online: https://www.overshootday.org/newsroom/press-release-june2019-english/ (accessed on 5 December 2019).

3. European Environment Agency Europe's State of the Environment 2020: Change of Direction Urgently Needed to Face Climate Change Challenges, Reverse Degradation and Ensure Future Prosperity-European Environment Agency. Available online: https:/www.eea.europa.eu/highlights/ soer2020-europes-environment-state-and-outlook-report (accessed on 14 December 2019).

4. Mont, O.; Whalen, K.; Nussholz, J. Sustainable innovation in business models: Celebrated but not interrogated. In Handbook of Sustainable Innovation; Edward Elgar Publishing: Cheltenham, UK; Northhampton, MA, USA, 2019; pp. 124-140, ISBN 978-1-78811-257-4.

5. Mont, O. Clarifying the concept of product-service system. J. Clean. Prod. 2002, 10, 237-245. [CrossRef]

6. Tukker, A. Eight types of product-service system: Eight ways to sustainability? Experiences from SusProNet. Bus. Strategy Environ. 2004, 13, 246-260. [CrossRef]

7. Stål, H.I.; Corvellec, H. A decoupling perspective on circular business model implementation: Illustrations from Swedish apparel. J. Clean. Prod. 2018, 171, 630-643. [CrossRef]

8. Svensk Handel. Starkt Ökat Hållbarhetsintresse Hos Konsumenterna Och Handelsföretagen Är Redo; Svensk Handel: Stockholm, Sweden, 2018. Available online: https://www.svenskhandel.se/globalassets/dokument/aktuelltoch-opinion/rapporter-och-foldrar/hallbar-handel/svensk-handels-hallbarhetsundersokning-2018.pdf (accessed on 7 June 2020).

9. Åkerlund, C. Hyrkläder Ger Hållbart Mode. Available online: https://www.di.se/hallbart-naringsliv/ hyrklader-ger-hallbart-mode/ (accessed on 21 April 2020).

10. Mont, O. Product-Service Systems: Panacea or Myth? Ph.D. Thesis, Lund University, Lund, Sweden, 2004.

11. Tukker, A. Product services for a resource-efficient and circular economy-A review. J. Clean. Prod. 2015, 97, 76-91. [CrossRef]

12. Stahel, W. The Performance Economy; Palgrave-Macmillan: London, UK, 2010; ISBN 0230007961.

13. Retamal, M. Product-service systems in Southeast Asia: Business practices and factors influencing environmental sustainability. J. Clean. Prod. 2017, 143, 894-903. [CrossRef]

14. Pialot, O.; Millet, D.; Bisiaux, J. "Upgradable PSS": Clarifying a new concept of sustainable consumption/production based on upgradablility. J. Clean. Prod. 2017, 141, 538-550. [CrossRef]

15. Catulli, D.; Reed, N.; Tzilivakis, J.; Green, A. Extending the Life of Infant Mobility Products: Implementing a Product Service System: Report on DEFRA ABR112 (Project EV0534)/Re-Engineering Business for Sustainability; University of Hertfordshire: Hatfield, UK, 2020.

16. Baines, T.S.; Lightfoot, H.W.; Evans, S.; Neely, A.; Greenough, R.; Peppard, J.; Roy, R.; Shehab, E.; Braganza, A.; Tiwari, A.; et al. State-of-the-art in product-service systems. Proc. Inst. Mech. Eng. Part B J. Eng. Manuf. 2007, 221, 1543-1552. [CrossRef]

17. Winther, S. Uthyrning—Detaljhandelsbutikernas Vapen Mot e-Handeln. Sver. Radio. 2019. Available online: https://sverigesradio.se/artikel/7288622 (accessed on 30 January 2020).

18. Kärnström, M. Råd\&Rön—Hyra Kläder—Gammalt Säljknep i ny Kostym. Available online: https://www. radron.se/artiklar/hyra-klader--gammalt-saljknep-i-ny-kostym/ (accessed on 30 January 2020).

19. Besch, K. Product-service systems for office furniture: Barriers and opportunities on the European market. J. Clean. Prod. 2005, 13, 1083-1094. [CrossRef]

20. Tan, A.R.; Matzen, D.; McAloone, T.C.; Evans, S. Strategies for designing and developing services for manufacturing firms. CIRP J. Manuf. Sci. Technol. 2010, 3, 90-97. [CrossRef]

21. Kristensen, H.S.; Remmen, A. A framework for sustainable value propositions in product-service systems. J. Clean. Prod. 2019, 223, 25-35. [CrossRef] 
22. Mont, O. Innovative approaches to optimising design and use of durable consumer goods. Int. J. Prod. Dev. 2008, 6, 227-250. [CrossRef]

23. Tukker, A.; Tischner, U. New Business for Old Europe. Product Services, Sustainability and Competitiveness; Greenleaf Publishing Ltd.: Sheffield, UK, 2006.

24. Donatello, S.; Caldas, M.G.; Wolf, O. Revision of the EU Green Public Procurement (GPP) Criteria for Furniture; Publications Office of the European Union: Luxembourg, 2017; p. 149.

25. Sandin, G.; Roos, S.; Spak, B.; Zamani, B.; Peters, G. Environmental assessment of Swedish clothing consumption-Six garments, Sustainable Futures. Göteborg: Mistra Future Fashion. 2019. Available online: http://mistrafuturefashion.com/wp-content/uploads/2019/08/G.Sandin-Environmental-assessmentof-Swedish-clothing-consumption.MistraFutureFashionReport-2019.05.pdf (accessed on 30 August 2020).

26. Rexfelt, O.; Hiort af Ornäs, V. Consumer acceptance of product-service systems: Designing for relative advantages and uncertainty reductions. J. Manuf. Technol. Manag. 2009, 20, 674-699. [CrossRef]

27. Gullstrand Edbring, E.; Lehner, M.; Mont, O. Exploring consumer attitudes to alternative models of consumption: Motivations and barriers. J. Clean. Prod. 2016, 123, 5-15. [CrossRef]

28. Vezzoli, C.; Ceschin, F.; Diehl, J.C.; Kohtala, C. New design challenges to widely implement "Sustainable Product-Service Systems" . J. Clean. Prod. 2015, 97, 1-12. [CrossRef]

29. Catulli, M.; Cook, M.; Potter, S. Consuming use orientated product service systems: A consumer culture theory perspective. J. Clean. Prod. 2017, 141, 1186-1193. [CrossRef]

30. Dos Santos, P.S.; Campos, L.M.S.; Cauchick Miguel, P.A. Adoption of product-service system and the potential as a sustainable solution: A literature view in the fashion industry. In Proceedings of the International Conference on Industrial Engineering and Operations Management, Pilsen, Czech Republic, 23-26 July 2019.

31. Lee, S.; Geum, Y.; Lee, S.; Park, Y. Evaluating new concepts of PSS based on the customer value: Application of ANP and niche theory. Expert Syst. Appl. 2015, 42, 4556-4566. [CrossRef]

32. Johnson, E. Dressing Up the Environmental Potential for Product-Service Systems: A Comparative Life Cycle Assessment on Consumption in Rental Clothing vs. Linear Business Models. Master's Thesis, Lund University, Lund, Sweden, 2020; p. 130. Available online: https://lup.lub.lu.se/luur/download?func= downloadFile\&recordOId $=9025941 \&$ fileOId $=9025943$ (accessed on 5 September 2020).

33. Day, S.; Godsell, J.; Masi, D.; Zhang, W. Predicting consumer adoption of branded subscription services: A prospect theory perspective. Bus. Strategy Environ. 2020, 29, 1310-1330. [CrossRef]

34. Fota, A.; Wagner, K.; Schramm-Klein, H. Will Renting Substitute Buying? Drivers of User Intention to Participate in Rental-Commerce. In Proceedings of the 27th European Conference on Information Systems, Stockholm \& Uppsala, Sweden, 8-14 June 2019. Available online: https://aisel.aisnet.org/ecis2019_rp/80?utm_source=aisel.aisnet.org\%2Fecis2019_rp\%2F80\&utm_ medium=PDF\&utm_campaign=PDFCoverPages (accessed on 21 August 2020).

35. Baden, D.; Peattie, K.; Oke, A. Access Over Ownership: Case Studies of Libraries of Things. Sustainability 2020, 12, 7180. [CrossRef]

36. Armstrong, C.M.; Niinimäki, K.; Kujala, S.; Karell, E.; Lang, C. Sustainable product-service systems for clothing: Exploring consumer perceptions of consumption alternatives in Finland. J. Clean. Prod. 2015, 97, 30-39. [CrossRef]

37. Pedersen, E.R.G.; Netter, S. Collaborative Consumption: Business Model Opportunities and Barriers for Fashion Libraries. J. Fash. Mark. Manag. 2015, 19, 258-273. [CrossRef]

38. Schaefers, T.; Lawson, S.J.; Kukar-Kinney, M. How the burdens of ownership promote consumer usage of access-based services. Mark. Lett. 2016, 27, 569-577. [CrossRef]

39. Mont, O.; Lehner, M.; Schoonover, H. Business Models for Sustainable Consumption. Inspirational Examples from Furniture and Home Textiles Sectors; Lund University: Lund, Sweden, 2020; p. 50.

40. Sumter, D.; Bakker, C.; Balkenende, R. The role of product design in creating circular business models: A case study on the lease and refurbishment of baby strollers. Sustainability 2018, 10, 2415. [CrossRef]

41. Corvellec, H.; Stål, H.I. Evidencing the waste effect of product-service systems (PSSs). J. Clean. Prod. 2017, 145, 14-24. [CrossRef]

42. Lawson, S.J.; Gleim, M.R.; Perren, R.; Hwang, J. Freedom from ownership: An exploration of access-based consumption. J. Bus. Res. 2016, 69, 2615-2623. [CrossRef] 
43. Tunn, V.S.C.; Fokker, R.; Luijkx, K.A.; De Jong, S.A.M.; Schoormans, J.P.L. Making Ours Mine: Increasing Consumer Acceptance of Access-Based PSS through Temporary Product Customisation. Sustainability 2019, 11, 274. [CrossRef]

44. Armstrong, C.M.; Niinimäki, K.; Lang, C.; Kujala, S. A Use-Oriented Clothing Economy? Preliminary Affirmation for Sustainable Clothing Consumption Alternatives: A Use-Oriented Clothing Economy? Sustain. Dev. 2016, 24, 18-31. [CrossRef]

45. D'Agostin, A.; de Medeiros, J.F.; Vidor, G.; Zulpo, M.; Moretto, C.F. Drivers and barriers for the adoption of use-oriented product-service systems: A study with young consumers in medium and small cities. Sustain. Prod. Consum. 2020, 21, 92-103. [CrossRef]

46. Poppelaars, F.; Bakker, C.; van Engelen, J. Does access trump ownership? Exploring consumer acceptance of access-based consumption in the case of smartphones. Sustain. Switz. 2018, 10, 2133. [CrossRef]

47. Cherry, C.E.; Pidgeon, N.F. Why is ownership an issue? Exploring factors that determine public acceptance of product-service systems. Sustain. Switz. 2018, 10, 2289. [CrossRef]

48. Rousseau, S. Millennials' acceptance of product-service systems: Leasing smartphones in Flanders (Belgium). J. Clean. Prod. 2020, 246, 118992. [CrossRef]

49. Catulli, M.; Lindley, J.K.; Reed, N.B.; Green, A.; Hyseni, H.; Kiri, S. What is Mine is not Yours: Further Insight on what Access-Based Consumption says about Consumers. In Research in Consumer Behavior; Belk, R.W., Price, L., Peñaloza, L., Eds.; Emerald Group Publishing Limited: Bingley, UK, 2013; Volume 15, pp. 185-208, ISBN 978-1-78190-810-5.

50. Clube, R.K.M.; Tennant, M. Exploring garment rental as a sustainable business model in the fashion industry: Does contamination impact the consumption experience? J. Consum. Behav. 2020. [CrossRef]

51. Akbar, P.; Hoffmann, S. Under which circumstances do consumers choose a product service system (PSS)? Consumer benefits and costs of sharing in PSS. J. Clean. Prod. 2018, 201, 416-427. [CrossRef]

52. Mont, O.; Plepys, A. Customer Satisfaction: Review of Literature and Application to the Product-Service Systems; The Society for Non-Traditional Technology: Tokyo, Japan, 2003; p. 61.

53. Bohlin, A. 'It will Keep Circulating': Loving and Letting Go of Things in Swedish Second-hand Markets. Worldw. Waste J. Interdiscip. Stud. 2019, 2, 3. [CrossRef]

54. Bardhi, F.; Eckhardt, G.M. Access-Based Consumption: The Case of Car Sharing. J. Consum. Res. 2012, 39, 881. [CrossRef]

55. Singh, P.; Giacosa, E. Cognitive biases of consumers as barriers in transition towards circular economy. Manag. Decis. 2019, 57, 921-936. [CrossRef]

56. Sánchez-Fernández, R.; Iniesta-Bonillo, M.Á. The concept of perceived value: A systematic review of the research. Mark. Theory 2007, 7, 427-451. [CrossRef]

57. Walsh, G.; Shiu, E.; Hassan, L.M. Replicating, validating, and reducing the length of the consumer perceived value scale. J. Bus. Res. 2014, 67, 260-267. [CrossRef]

58. Woodruff, R.B. Customer value: The next source for competitive advantage. J. Acad. Mark. Sci. 1997, 25, 139-153. [CrossRef]

59. Sweeney, J.C.; Soutar, G.N. Consumer perceived value: The development of a multiple item scale. J. Retail. 2001, 77, 203-220. [CrossRef]

60. Schrader, U. Consumer Acceptance of Eco-Efficient Services. A German Perspective. Greener Manag. Int. 1999, 25, 105-122.

61. Mont, O.; Tukker, A. Product-Service Systems: Reviewing achievements and refining the research agenda. J. Clean. Prod. 2006, 14, 1451-1454. [CrossRef]

62. Mont, O. Reducing life-cycle environmental impacts through systems of joint use. Greener Manag. Int. 2004, 2004, 63-77. [CrossRef]

63. Shrivastava, A.; Jain, G.; Kamble, S.S.; Belhadi, A. Sustainability through online renting clothing: Circular fashion fueled by instagram micro-celebrities. J. Clean. Prod. 2020, 278. [CrossRef]

64. Yin, R.K. Case Study Research: Design and Methods, 3rd ed.; Applied Social Research Methods Series; Sage Publications: Thousand Oaks, CA, USA, 2003; ISBN 978-0-7619-2552-1.

65. Osterwalder, A.; Pigneur, Y. Business Model Generation: A Handbook for Visionaries, Game Changers, and Challengers; Wiley Desktop Editions: Hoboken, NJ, USA, 2010.

66. Blaikie, N.; Priest, J. Designing Social Research: The Logic of Anticipation; Polity Press: Cambridge, UK, 2019; ISBN 1-5095-1744-8. 
67. Gomm, R.; Hammersley, M.; Foster, P. Case Study Method: Key Issues, Key Texts; SAGE Publications: London, UK, 2000; ISBN 1-4739-0318-1.

68. Fink, A. Conducting Research Literature Reviews: From the Internet to Paper; Sage Publications: Thousand Oaks, CA, 2013.

69. Efron, S.E.; Ravid, R. Writing the Literature Review: A Practical Guide; Guilford Publications: New York, NY, USA, 2018.

70. Blaikie, N. Approaches to Social Enquiry; Polity Press: Cambridge, UK, 1993.

71. Okoli, C. A guide to conducting a standalone systematic literature review. Commun. Assoc. Inf. Syst. 2015, 37, 879-910. [CrossRef]

72. Mont, O. Drivers and barriers for shifting towards more service-oriented businesses: Analysis of the PSS field and contributions from Sweden. J. Sustain. Prod. Des. 2002, 2, 89-103. [CrossRef]

73. Pocheptsova, A.; Kivetz, R.; Dhar, R. Consumer Decisions to Rent vs. Buy. In NA-Advances in Consumer Research Volume 35; Lee, A.Y., Soman, D., Eds.; Association for Consumer Research: Duluth, MN, USA, 2008.

74. Pantano, E.; Stylos, N. The Cinderella moment: Exploring consumers' motivations to engage with renting as collaborative luxury consumption mode. Psychol. Mark. 2020, 37, 740-753. [CrossRef]

75. Tukker, A.; Tishner, U. Product-services as a research field: Past, present and future. Reflections from a decade of research. J. Clean. Prod. 2006, 14, 1552-1556. [CrossRef]

76. Hazée, S.; Delcourt, C.; Van Vaerenbergh, Y. Burdens of Access: Understanding Customer Barriers and Barrier-Attenuating Practices in Access-Based Services. J. Serv. Res. 2017, 20, 441-456. [CrossRef]

77. Mont, O.; Dalhammar, C.; Jacobsson, N. A new business model for baby prams based on leasing and product remanufacturing. J. Clean. Prod. 2006, 14, 1509-1518. [CrossRef]

78. Mont, O.; Plepys, A. System Perspective on Service Provision: A case of community-based washing centres for households. Int. J. Public Aff. 2007, 3, 130-151.

(C) 2020 by the authors. Licensee MDPI, Basel, Switzerland. This article is an open access article distributed under the terms and conditions of the Creative Commons Attribution (CC BY) license (http://creativecommons.org/licenses/by/4.0/). 